\title{
Analysis of Modes of Asynchronized Generator in Extra-High Voltage Power Grid
}

\author{
Kostiantyn Pokrovskyi ${ }^{*}$, Andriy Muzychak, Olgerd Mavrin, Volodymyr Oliinyk \\ Lviv Polytechnic National University, 12 Stepana Bandery St., Lviv, 79013, Ukraine
}

Received: October 08, 2019. Revised: November 18, 2019. Accepted: November 25, 2019.

(C) 2019 The Authors. Published by Lviv Polytechnic National University.

\begin{abstract}
The use of extra-high voltage networks leads to a number of problems with compensation for excess reactive power. An option to avoid these problems is to apply asynchronized synchronous turbine generators, which have a number of advantages over traditional synchronous generators. These advantages are largely manifested under conditions of generator operation in power grids with excess reactive power. Typical examples of such power grids are power grid "Burshtyn Island" and "Power bridge "Ukraine-EU". The article presents the results of mathematical modelling of the steady-state modes for "Power bridge "Ukraine-EU". The mode coordinates are determined under different conditions regarding reactive power particularly with using an asynchronized turbine generator in asynchronous as well as asynchronized modes. The results obtained prove the feasibility and effectiveness of the proposed technical solution.
\end{abstract}

Keywords: asynchronized generator; asynchronized mode; asynchronous mode; reactive power; extra-high voltage power grid; "Power bridge "Ukraine-EU".

\section{Definition of the problem to be solved}

One of the consequences of the load curve unevenness in the power system is the generation of surplus reactive power in the grid during night and day off-peak load. This necessitates the applying of reactive power compensation equipment. In extra-high voltage grids, the standard solution for compensation is the using of shunt reactors. An example of shunt reactors use could be operating power grid "Burshtyn Island" with Burshtyn thermoelectric power station (BuTES). "Burshtyn Island" is isolated from the Ukrainian power system and national power company "Ukrenergo" (NPC "Ukrenergo") (Fig.1). "Burshtyn Island" started its parallel work with European energy association UCTE (Union for the Coordination of Transmission of Electricity) and now keeps on its work with the European Network of transmission system operators (ENTSO-E). The following notations are used in Fig.1: ZU TS - Zakhidnoukrainska transforming station (there are two autotransformers AT1 and AT2), KhNPP - Khmelnitskiy Nuclear Power Plant (there are two generating units GU1 and GU2). All energy facilities are connected through the overhead power lines (OHL $750 \mathrm{kV}$ and $\mathrm{OHL} 400 \mathrm{kV}$ ). In order to ensure reactive power compensation in the scheme, there are used the compensative shunt reactors RODC-110000/750 which are single phase reactors with the forced circulation of air and oil.

In the scheme of "Power bridge "Ukraine-EU" the same shunt reactors are also required. The "Power bridge "Ukraine-EU" is one of the possible projects for further expansion of power grid "Burshtyn Island" with the junction of GU2 of Khmelnitskiy Nuclear Power Plant [1].

*Corresponding author. Email address: kpokrov@gmail.com

This paper should be cited as: K. Pokrovskyi, A. Muzychak, O. Mavrin, V. Oliinyk. Analysis of modes of asynchronized generator in extra-high voltage power grid. Energy Engineering and Control Systems, 2019, Vol. 5, No. 2, pp. 57 - 65. https://doi.org/10.23939/jeecs2019.02.057 
The additional electricity export to the European power system is planned through the existing overhead power lines (OHL) $750 \mathrm{kV}$ "KhNPP - Rzeszow (Republic of Poland)" and "KhNPP Zakhidnoukrainska transforming station (ZU TS)". The one-line diagram of "Power bridge "Ukraine-EU" according to [1] is given in Fig.2.

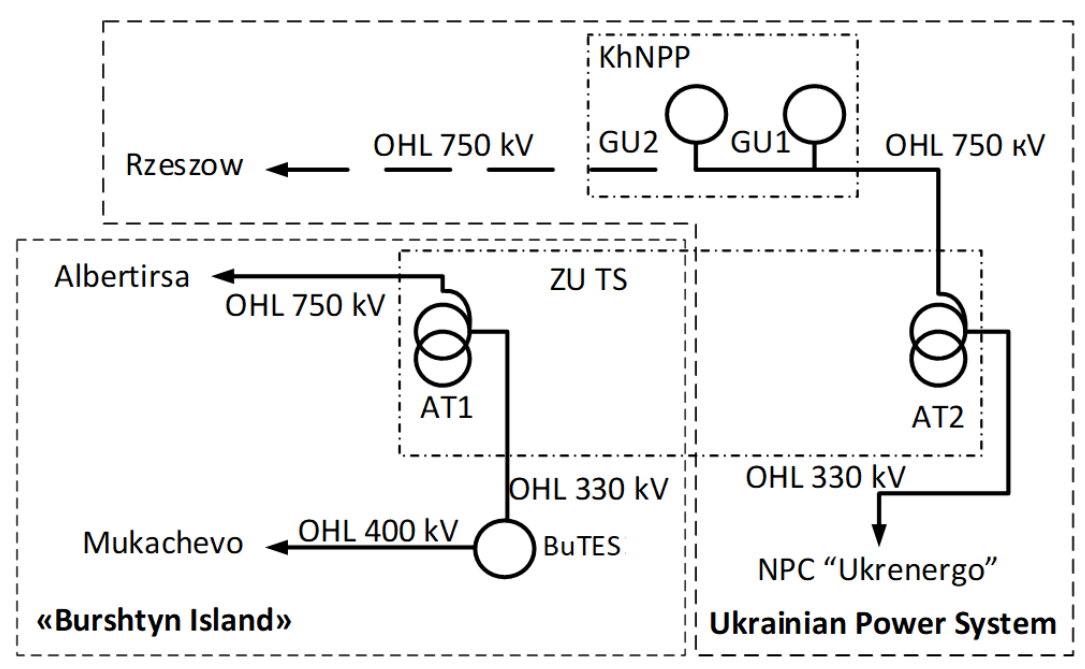

Fig.1. The one-line diagram of "Burshtyn Island".

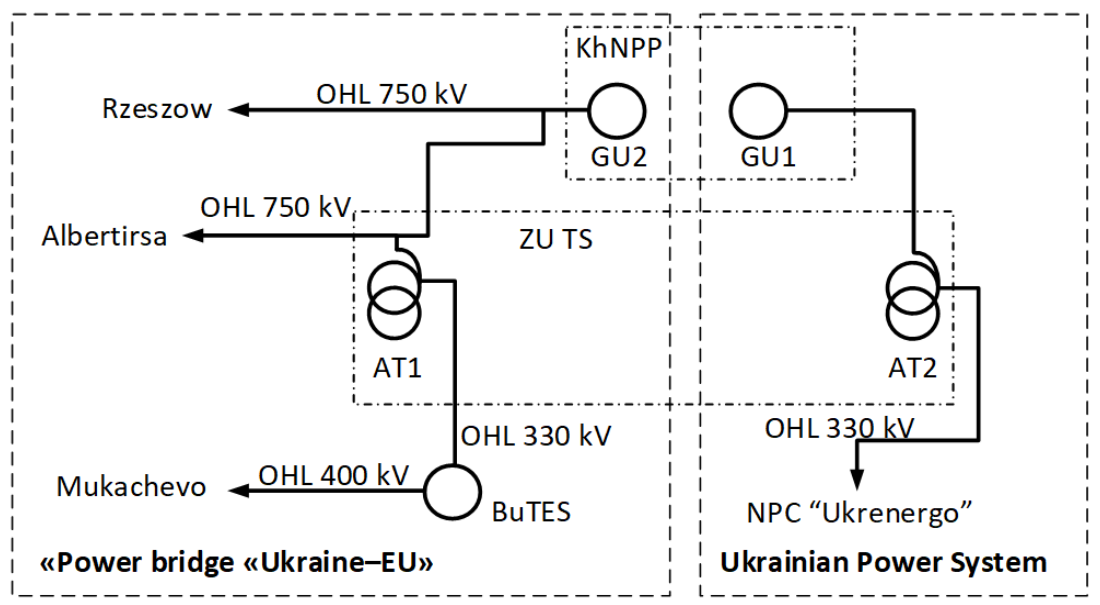

Fig.2. The proposed one-line diagram of "Power bridge "Ukraine-EU".

The main disadvantage of above mentioned shunt reactors is their step regulation. In addition, their usage in extra-high-voltage electricity grids causes certain defects [2] due to which, in particular, the electrical properties of the oil exceed the limits of permissible standards [3]. Such defects make further normal operation of the reactors impossible. At the same time, a too wide range of step regulation causes one more problem, namely the occurrence of excessive reactive power in the system during periods of incomplete loading.

Due to the widespread of shunt reactors in domestic electricity grids $750 \mathrm{kV}$, the relevance of the above mentioned problems will remain even under the condition of future integration of the energy systems of Ukraine and Europe.

The possible option to deal with these problems is to apply asynchronized synchronous turbine generators (ASTG) instead of traditional synchronous generators. The applying of an asynchronized synchronous type generator on power plants allows significantly increasing the reliability of electricity generation due to different operative modes of the generator [4]. 


\section{Analysis of the recent publications and research works on the problem}

A number of well-known works [4]-[10] are devoted to the operating characteristics of ASTG in conditions of high voltage networks, but information on the performance of ASTG-1000MW in $750 \mathrm{kV}$ extra-high voltage networks is missing.

The advantages of ASTG in comparison with traditional synchronous generators are especially evident under conditions of generators operation in electricity grids with excess reactive power, which also include grids $750 \mathrm{kV}$.

An asynchronized generator, unlike a traditional synchronous generator, can practically without any limitations operate in a synchronous mode (under conditions of biaxial and uniaxial excitation), in an asynchronized mode (with deep reactive power consumption and in compliance with the requirements for stability and heating of extreme stator packages) and in an asynchronous mode (in the absence of an excitation system).

\section{Formulation of the goal of the paper}

The purpose of the article is to analyze the operating modes of the asynchronized generator ASTG-1000 and to prove their effectiveness under different conditions. All calculations are performed for the "Power bridge "Ukraine-EU", as a typical example of the power grid with excess reactive power, possible shutdowns of the shunt reactors and without reactive power take-off from buses $750 \mathrm{kV}$.

\section{Presentation and discussion of the research results}

\subsection{The options of the operating scheme}

The calculation scheme of the power bridge is shown in Fig.3. The scheme consists of "Burshtyn Island" grid and transformer station "Rzeszow", which are represented by energy systems S1 and S2 respectively. The scheme also comprises two overhead power lines $750 \mathrm{kV}$ OHL1 and OHL2 with compensative shunt reactors SR1..SR4, transformer $\mathrm{T}$ and a synchronous generator $\mathrm{G}$ of KhNPP GU2. The auxiliaries of generating unit GU2 of KhNPP are also taken into account. The traditional synchronous generator in the steady-state mathematical model represented by the sources of active and reactive power with restrictions on consumption of reactive power [5]. The generator type is TVV-1000-2U3, the shunt reactors type is RODC-110000/750 and the transformer type is $3 \times$ ORC-417/750. To calculate the steady-state modes and transition processes of the "Power bridge" scheme, a mathematical model of the energy grid has been developed and tested [6]. The obtained mathematical model allows evaluating the parameters influence of synchronous and asynchronized generators on steady-state modes of the scheme under different conditions.

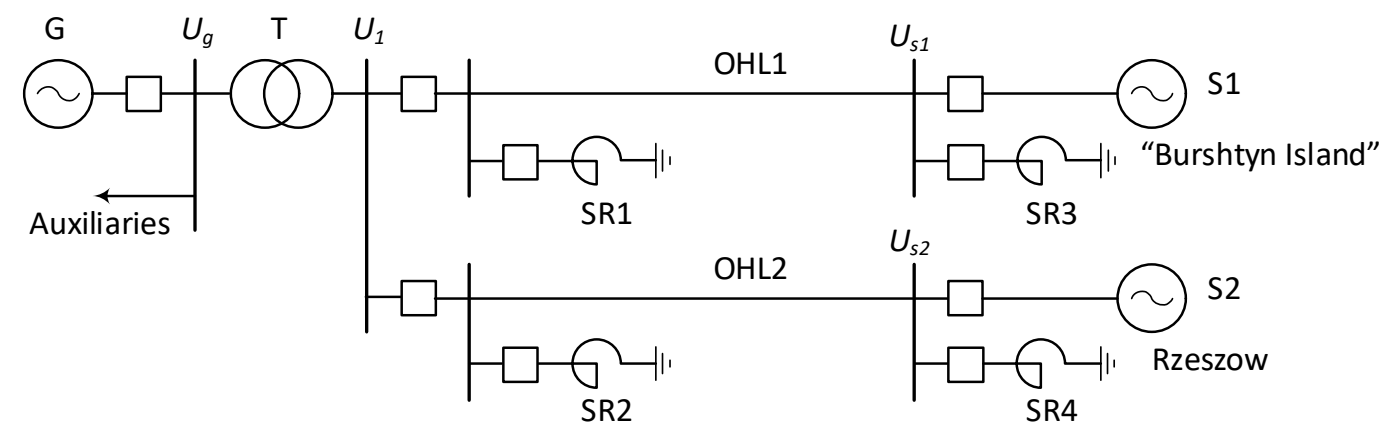

Fig.3.The calculation scheme of the "Power bridge".

The approbation of the mathematical model of power bridge "Ukraine-EU" in PowerFactory program was verified by comparing the calculated mode coordinates with the results of control measurements. These control measurements are regularly carried out by an operational staff of the Western Electric Power System of NPC "Ukrenergo". The results of the comparison proved the adequacy of the mathematical model [6].

The permissible operating modes for the synchronous generator are defined by the limits of regulation for active and reactive power. For the synchronous generator of a nuclear power plant, there is no active power regulation, and limits of reactive power regulation are given in Table 1. 
Table 1. The permissible modes regarding the reactive power of the synchronous generator.

\begin{tabular}{|c|c|c|}
\hline \multicolumn{3}{|c|}{ Main mode parameters of the synchronous generator } \\
\hline$P, \mathrm{MW}$ & $Q_{\min }$, Mvar & $Q_{\max }$, Mvar \\
\hline 1000 & -53.2 & 484.5 \\
\hline
\end{tabular}

The synchronous generator allows the regulation of reactive power in wide limits only in the first quadrant (from 0 Mvar to 484.5 Mvar). The selectable coordinates obtained with the developed mathematical model are given in Table 2 (for the variant 1 and the variant 2) and in Table 3 (for the variant 3 ).

Table 2. Steady-state mode coordinates in the scheme with synchronous generator for the variants 1 and 2 .

\begin{tabular}{|c|c|c|c|}
\hline \multirow{4}{*}{ Variant } & $\begin{array}{c}\text { The mode } \\
\text { coordinates }\end{array}$ & \multicolumn{2}{|c|}{ Shunt reactors which are switched off } \\
\cline { 2 - 4 } & $P_{g}, \mathrm{MW}$ & 1000 & SRI \\
\cline { 2 - 4 } & $Q_{g}, \mathrm{Mvar}$ & 36 & 1000 \\
\cline { 2 - 4 } & $U_{g}, \mathrm{pu}$ & 1.12 & 36 \\
\cline { 2 - 4 } & $U_{\mathrm{l}}, \mathrm{pu}$ & 1.18 & 1.12 \\
\cline { 2 - 4 } & $U_{s}, \mathrm{pu}$ & 1.0 & 1.18 \\
\hline \multirow{4}{*}{$\begin{array}{c}\text { Variant } \\
2\end{array}$} & $P_{g}, \mathrm{MW}$ & 1000 & 1.0 \\
\cline { 2 - 4 } & $Q_{g}, \mathrm{Mvar}$ & 309 & 1000 \\
\cline { 2 - 4 } & $U_{g}, \mathrm{pu}$ & 1.03 & 309 \\
\cline { 2 - 4 } & $U_{\mathrm{l}}, \mathrm{pu}$ & 1.05 & 1.03 \\
\cline { 2 - 4 } & $U_{s}, \mathrm{pu}$ & 1.0 & 1.05 \\
\hline
\end{tabular}

Table 3. Steady-state mode coordinates in the scheme with synchronous generator for the variant 3 .

\begin{tabular}{|c|c|c|c|}
\hline \multirow{2}{*}{ Variant } & \multirow{2}{*}{$\begin{array}{l}\text { The mode } \\
\text { coordinates }\end{array}$} & \multicolumn{2}{|c|}{ Shunt reactors which are switched off } \\
\hline & & $S R 1$ and $S R 3$ & all shunt reactors \\
\hline \multirow{5}{*}{$\begin{array}{c}\text { Variant } \\
3\end{array}$} & $P_{g}, \mathrm{MW}$ & 1000 & 1000 \\
\hline & $Q_{g}$, Mvar & 36 & 36 \\
\hline & $U_{g}, \mathrm{pu}$ & 1.02 & 1.02 \\
\hline & $U_{\mathrm{l}}, \mathrm{pu}$ & 1.08 & 1.08 \\
\hline & $U_{s}, \mathrm{pu}$ & 1.0 & 1.0 \\
\hline
\end{tabular}

The presented results demonstrate that the restriction on the consumption of reactive power of an ordinary synchronous generator results in a narrowing of the voltage control band on the generator voltage bus and on the $750 \mathrm{kV}$ KhNPP bus. There is also the excess of a permissible standard $5 \%$ for a class voltage of $750 \mathrm{kV}$ under conditions of the nominal voltage on power system buses, what is caused by a violation of the reactive power balance.

\subsection{Mode coordination with asynchronized turbine generator}

Ukrainian plant "Electrotyazhmash" has got experience in designing of ASTG generators. Its asynchronized generators could provide reactive power generation as well as consumption in asynchronized and asynchronous mode without restrictions inherent synchronous generators [7]-[9]. ASTG asynchronized mode provides independent control by electromagnetic torque and reactive power under conditions of biaxial excitation. The possibility of deep reactive power consumption helps to compensate reactive power surpluses on the network. 
The ASTG asynchronous mode has a number of features. The asynchronized turbine generator in asynchronous mode with short-circuited excitation windings can constantly carry an active load while consuming reactive load with the only limit to stator current and turbine power [9]. Moreover, the mode is not accompanied by mode coordinates fluctuations inherent in synchronous machine and contributes to the stable operation of the power plant as a whole. For the mathematical modeling of the ASTG, the traditional equations are used, taking into account the symmetry of the rotor lobe on the $d, q$-axes and the equivalent contour of the circular array of the rotor (1).

$$
\left\{\begin{array}{l}
-u_{d}=(r+p x) i_{d}+p x_{a d}\left(i_{f d}+i_{r d}\right)+x i_{q}+x_{a d}\left(i_{f q}+i_{r q}\right) \\
-u_{d}=(r+p x) i_{d}+p x_{a d}\left(i_{f d}+i_{r d}\right)+x i_{q}+x_{a d}\left(i_{f q}+i_{r q}\right) \\
-u_{f q}=\left(r_{f}+p x_{f}\right) i_{f q}+p x_{a d}\left(i_{q}+i_{r q}\right)-s\left(x_{f} i_{f d}+x_{a d}\left(i_{d}+i_{r d}\right)\right) \\
-u_{f d}=\left(r_{f}+p x_{f}\right) i_{f d}+p x_{a d}\left(i_{d}+i_{r d}\right)-s\left(x_{f} i_{f q}+x_{a d}\left(i_{q}+i_{r q}\right)\right) \\
0=\left(r_{r}+p x_{r}\right) i_{r q}+p x_{a d}\left(i_{q}+i_{f q}\right)-s\left(x_{r} i_{r d}+x_{a d}\left(i_{d}+i_{f d}\right)\right) \\
0=\left(r_{r}+p x_{r}\right) i_{r d}+p x_{a d}\left(i_{d}+i_{f d}\right)-s\left(x_{r} i_{r q}+x_{a d}\left(i_{q}+i_{f q}\right)\right) \\
T_{j} p S=M t-M
\end{array}\right.
$$

where $u_{d}, u_{q}$ are stator voltage projections on $d, q$-axis; $i_{d}, i_{q}$ are stator current projections on $d, q$-axis; $i_{f d}, i_{f q}$ are exciting current projections on $d, q$-axis; $i_{r d}, i_{r q}$ are current projections of rotor array on $d, q$-axis; $s$ is slip of a generator; $T_{j}$ is the inertia time constant of masses of generator block and turbine; $M$ is the electromagnetic torque of a generator; $M_{m}$ is the mechanical torque of a turbine; $r$ is the active resistance of the stator winding; $r_{r}=f(s)$ is the active resistance of rotor array as function of slip; $r_{f}$ is the active resistance of the exciting winding; $x_{r}=x_{a d}+x_{r}$; $x_{a d}$ is the inductive reactance of mutual inductance between stator and rotor windings; $x_{r}=f(s)$ is the inductive reactance of rotor array as function of slip; $x=x_{s}+x_{a d} ; x_{f s}$ is the inductive reactance of rotor windings scattering; $p$ is the differentiation operator.

To analyze the steady-state modes of ASTG, the transition to complex plane is done taking $p=0$. After the transformations, the equations (2) are obtained

$$
\left\{\begin{array}{l}
-\overline{\mathbf{U}}=r \overline{\mathbf{I}}+j\left(x \overline{\mathbf{I}}+x_{a f}\left(\overline{\mathbf{I}}_{f}+\overline{\mathbf{I}}_{r}\right)\right) \\
\bar{U}_{f}=r_{f} \overline{\mathbf{I}}_{f}-j s\left(x_{f} \overline{\mathbf{I}}+x_{a f}\left(\overline{\mathbf{I}}+\overline{\mathbf{I}}_{r}\right)\right) \\
0=r_{r} \overline{\mathbf{I}}_{r}-j s\left(x_{r} \overline{\mathbf{I}}+x_{a f}\left(\overline{\mathbf{I}}_{f}+\overline{\mathbf{I}}\right)\right)
\end{array}\right.
$$

where $\overline{\boldsymbol{U}}, \overline{\boldsymbol{U}}_{f}$ are the stator voltage and the exciting voltage of turbine generator; $\overline{\boldsymbol{I}}, \overline{\boldsymbol{I}}_{\mathrm{f}}, \overline{\boldsymbol{I}}_{\mathrm{r}}$ are the stator current, the exciting current and the current of rotor array. To simulate the asynchronized mode it is acceptable to take $s=0$, and for asynchronous mode with short-circuited rotor windings, the excitation voltage is equal to 0 . The approximation of the table dependencies [9] of the rotor contours parameters from a slip in asynchronous mode allowed obtaining the following expressions for resistance and reactance [10]

$$
r_{r}=A_{r}+B r / s ; \quad x_{r}=A_{x}+B_{x} / s
$$

where $r_{r}, x_{r}$ are the resistance and reactance of the rotor array, p.u.; $A_{r}, B_{r}, A_{x}, B_{x}$ are the constant coefficients obtained as a result of approximation. Simulation of transformers, overhead power lines, and power systems is carried out using traditional equivalent circuits.

The main task of ASTG in addition to electricity generation is the compensation of surplus reactive power that arises in a power system during hours of load falling down, in particular at night hours. During night load time ASTG in both asynchronized and asynchronous mode can consume reactive power and carry out a bit less active 
load. So that mode could be characterized as having greater reliability due to the absence of an excitation system. Taking into account the above, we can draw a conclusion about the possibility of using ASTG asynchronous mode as an additional operative mode in the scheme of the "Power bridge". The possibility is also supported by successful conducting of exploratory operation of the KhNPP generation unit GU2 in the mode of daily power control of generation unit [11].

It should be noted that the nuclear power units participation in regulating the power generation of Ukrainian power system represents an urgent issue for further nuclear power plants development. The generating union power reduction up to $75 \%$ approximately matches to the maximum ASTG-1000 power in asynchronous mode [9]. At the same time, the conclusion about the effectiveness of ASTG asynchronous mode applying should be confirmed or disproved by the results of complex task feasibility study solving under the conditions of a specific electrical grid scheme. The possible range of reactive power changes for the asynchronized turbine generator in asynchronized mode is given in Table 4.

Table 4. The permissible modes regarding the reactive power of the asynchronized turbine generator in asynchronized mode.

\begin{tabular}{|c|c|c|}
\hline \multicolumn{3}{|c|}{ Main mode parameters of the ASTG } \\
\hline$P, \mathrm{MW}$ & $Q_{\min }, \mathrm{Mvar}$ & $Q_{\max }$, Mvar \\
\hline 1000 & -484.5 & 484.5 \\
\hline
\end{tabular}

The calculated results for the scheme with ASTG-1000 are given in Table 5 (for the variant 1 and the variant 2) and in Table 6 (for the variant 3 ).

Table 5. Steady-State Mode coordinates in the scheme with asynchronized turbine generator in asynchronized mode for the Variant 1 and the Variant 2

\begin{tabular}{|c|c|c|c|}
\hline \multirow{4}{*}{ Variant } & $\begin{array}{c}\text { The mode } \\
\text { coordinates }\end{array}$ & \multicolumn{2}{|c|}{ Shunt reactors which are switched off } \\
\cline { 2 - 4 } & $P_{g}, \mathrm{MW}$ & 1000 & SRI \\
\hline \multirow{4}{*}{$\begin{array}{c}\text { Variant } \\
1\end{array}$} & $Q_{g}, \mathrm{Mvar}$ & -56 & 1000 \\
\cline { 2 - 4 } & $U_{g}, \mathrm{pu}$ & 0.97 & -356 \\
\cline { 2 - 4 } & $U_{l}, \mathrm{pu}$ & 1.04 & 0.94 \\
\cline { 2 - 4 } & $U_{s}, \mathrm{pu}$ & 1.0 & 1.04 \\
\hline \multirow{4}{*}{$\begin{array}{c}\text { Variant } \\
2\end{array}$} & $P_{g}, \mathrm{MW}$ & 1000 & 1.0 \\
\cline { 2 - 4 } & $Q_{g}, \mathrm{Mvar}$ & -56 & 1000 \\
\cline { 2 - 4 } & $U_{g}, \mathrm{pu}$ & 0.96 & -386 \\
\cline { 2 - 4 } & $U_{l}, \mathrm{pu}$ & 1.02 & 0.96 \\
\cline { 2 - 4 } & $U_{s}, \mathrm{pu}$ & 1.0 & 1.04 \\
\hline
\end{tabular}

In order to evaluate the transient processes in the scheme of the power bridge and their influence on mode coordinates, a series of mathematical experiments were conducted to simulate the processes of disconnecting the elements of the circuit.

Fig. 4 shows the transient process of OHL "KhNPP-ZU TS" disconnecting together with the corresponding shunt reactors SR1 and SR3 under the condition when the shunt reactor SR4 of OHL "KhNPP-Rzeszow" is in repair-disabled state. According to Fig.4 the active power of generator restores the original value during the transition process. 
Table 6. Steady-State Mode coordinates in the scheme with asynchronized turbine generator in asynchronous mode for the Variant 3

\begin{tabular}{|c|c|c|c|}
\hline Variant & $\begin{array}{c}\text { The mode } \\
\text { coordinates }\end{array}$ & \multicolumn{2}{|c|}{ Shunt reactors which are switched off } \\
\cline { 3 - 4 } & $P_{g}, \mathrm{MW}$ & 1000 & all shunt reactors \\
\hline \multirow{4}{*}{$\begin{array}{c}\text { Variant } \\
3\end{array}$} & $Q_{g}, \mathrm{Mvar}$ & -36 & 1000 \\
\cline { 2 - 4 } & $U_{g}, \mathrm{pu}$ & 0.95 & -56 \\
\cline { 2 - 4 } & $U_{1}, \mathrm{pu}$ & 1.01 & 0.96 \\
\cline { 2 - 4 } & $U_{s}, \mathrm{pu}$ & 1.0 & 1.01 \\
\hline
\end{tabular}
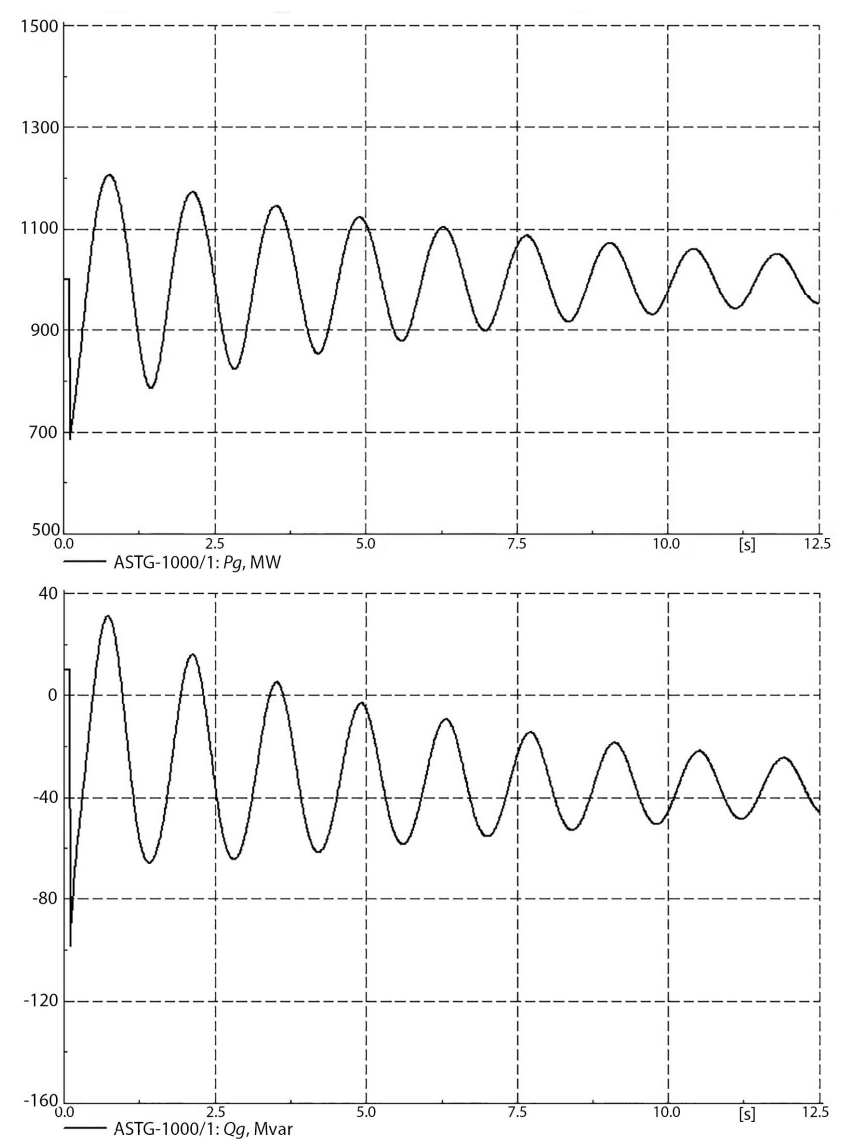

Fig.4. The power changing in the transient process of OHL "KhNPP-ZU TS" disconnecting when SR4 is in repair-disabled state.

Fig.5 shows the voltage changing in the transient process of OHL "KhNPP-ZU TS" under the same conditions. In this case, the voltages on the $750 \mathrm{kV}$ busses of Khmelnitskiy Nuclear Power Plant are within the permissible limits due to the generator ASTG-1000 switched to reactive power consumption mode.

The asynchronous mode ASTG-1000 is accompanied by a deep consumption of reactive power, which is limited to the maximum stator current of the generator and the turbine power. Reactive power generation in asynchronous mode is absent. 


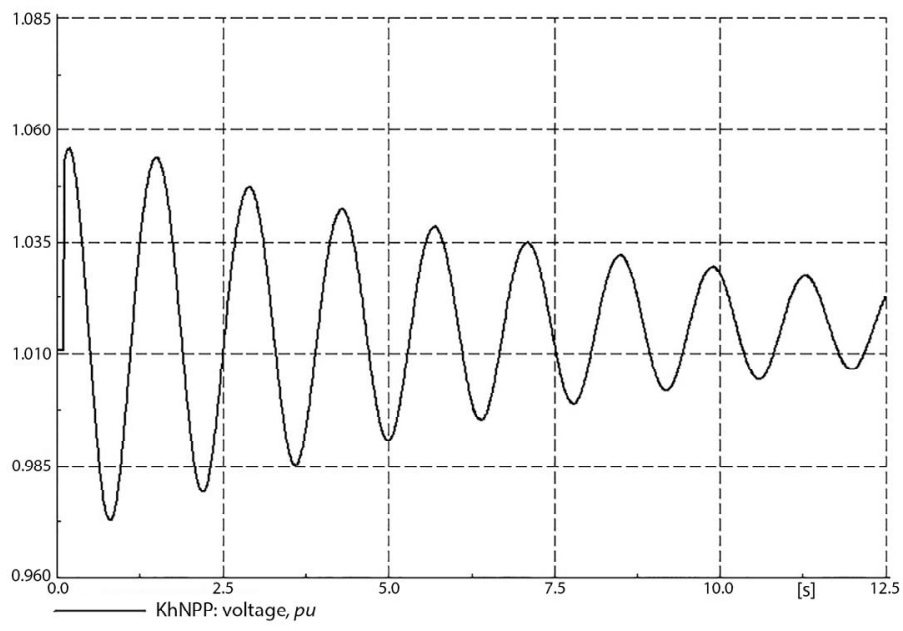

Fig.5. The voltage changing in the transient process of OHL "KhNPP-ZU TS" disconnecting when SR4 is in repair-disabled state.

In the mathematical model, the ASTG asynchronous mode was modelled by an asynchronous generator with a massive rotor and a shorted two-layer concentric exciting coil with the parameters obtained in [9]. The calculated results of steady-state mode coordinates for the variant 1 are given in Table 7 . In the mathematical model the 12\% voltage adjustment of the auxiliary transformer is also taken into account.

Table 7. Steady-state mode coordinates in the scheme with asynchronized turbine generator in asynchronous mode for the variant 1

\begin{tabular}{|c|c|c|}
\hline \multirow{4}{*}{ Variant } & $\begin{array}{c}\text { The mode } \\
\text { coordinates }\end{array}$ & Shunt reactors which are switched off \\
\cline { 3 - 3 } & $P_{g}, \mathrm{MW}$ & all shunt reactors \\
\cline { 2 - 3 } $\begin{array}{c}\text { Variant } \\
1\end{array}$ & $Q_{g}, \mathrm{Mvar}$ & 733 \\
\cline { 2 - 3 } & $U_{g}, \mathrm{pu}$ & -840 \\
\cline { 2 - 3 } & $U_{\mathrm{l}}, \mathrm{pu}$ & 0.88 \\
\cline { 2 - 3 } & $U_{s}, \mathrm{pu}$ & 1.05 \\
\hline
\end{tabular}

The obtained ASTG asynchronous mode coordinates for the scheme of "Power bridge "Ukraine-EU" allow making a conclusion about admissibility of asynchronous mode applying under the conditions of daily control of the generating unit power. The voltage deviation in all nodes of the scheme does not exceed the permissible limit of $5 \%$.

Calculations performed on the mathematical model prove a higher efficiency of ASTG asynchronized and asynchronous modes applying in the scheme of "Power bridge "Ukraine-EU" due to the forced transition of the generator to the of reactive power consumption mode as a result of switching in the grid.

\section{Conclusion}

The paper presents the results of the mathematical model development and testing for calculating the coordinates of the steady-state modes and transient processes of the "Power bridge "Ukraine - the European Union", the coordinates of the established modes of ASTG in the asynchronous and asynchronized modes, time characteristics of the transient processes. The calculated mode coordinates of the power-bridge scheme are determined by taking into account characteristics of the asynchronized turbine generator with power capacity $1000 \mathrm{MW}$. The obtained results show the high efficiency of applying reactive power consumption modes in the asynchronized and asynchronous modes of an ASTG, which reduces the necessity of shunt reactors using in "Power bridge "Ukraine-EU". Such technical solution could promote the increasing of scheme operation 
reliability and the widening of its possibilities to maintain the normal voltage levels in nodes with the general purpose to increase the efficiency of the energy system.

\title{
References
}

[1] Y. Nedashkovskyi. The pilot project "Energy Bridge Ukraine-EU" as the first step towards complete synchronization of power systems of Ukraine and the European Union. Energoatom of Ukraine, No. 1(44), pp. 5-9, 2017. (in Ukrainian)

[2] Nekrasov A.M., Rokotian S.S Long-distance power lines 750 kV. - Moscow: Energia, 1974. - book 1, p. 224. (in Russian)

[3] Guidelines for the diagnosis of developing defects in transformer equipment based on the results of chromatographic analysis of gases dissolved in oil. RD 153-34.0-46.302.00, Moscow, 2001. - 42 p. (in Russian)

[4] V. Zdanovskyi, O. Minyailo, V. Kryvyi. The operational experience of the asynchronized turbine generator ASTG-200. Electrical Stations, No. 1, pp. 37-41, 1993. (in Russian)

[5] M. Seheda, O. Minyailo, K. Pokrovskyy. Limitations in the economic distribution of reactive power between the generators. Przeglad Elektrotechniczny, No. 89(6), pp. 299-300, 2013.

[6] K. Pokrovskyy, O. Mavrin, A. Muzychak. Synchronous mode analysis of an asynchronized generator in the scheme of power bridge "Ukraine-EU". 2018 IEEE 3rd International Conference on Intelligent Energy and Power Systems. p. 85-89.

[7] Y. Zozulin, O. Antonov, V. Bychik, A. Borychevskyi, K. Kobzar, O. Livshyts, V. Rakohon, I. Rohovyi, L. Khaimovych, V. Cherednyk Creation of new types and modernization of existing turbine generators for thermoelectric power stations: [monograph]. - Kharkiv: Kolegium, 2011. - 223 p. (in Ukrainian)

[8] I. Postnikov, V. Asanbaev, A. Fink, V. Saratov, I. Cheremisov, Ju. Zozulin, D. Karpman. Research of parameters and characteristics of powerful asynchronized generators in synchronous mode: [Preprint 400]. IED AN Ukrainian SSR, Kiyiv, 1984, 42 p. (in Russian)

[9] I. Postnikov, V. Asanbaev, A. Fink, V. Saratov, I. Cheremisov, Ju. Zozulin, D. Karpman. Research of parameters and characteristics of powerful asynchronized generators in asynchronous mode: [Preprint 399]. IED AN Ukrainian SSR, Kiyiv, 1984, 52 p. (in Russian)

[10] Miniailo O.S., Pokrovskyi K.B. Static mathematical model of the block with ASTG. Technical Electrodynamics, No. 2, pp. 56-60, 1995.

[11] R. Glushenkov . Study of main aspects of implementation of the regime of day power regulation at Ukrainian NPS. Technical Audit and Production Preserves, No. 2/1(22), pp.18-26, 2015. (in Russian) DOI: 10.15587/2312-8372.2015.41404.

\section{Аналіз режимів асинхронізованого генератора у мережі надвисокої напруги}

\author{
Костянтин Покровський, Ольгерд Маврін, Андрій Музичак, Володимир Олійник \\ Наиіональний університет «Львівська політехніка», вул. С. Бандери 12, м. Львів, 79013, Україна
}

\section{Анотація}

Застосування мереж надвисокої напруги призводить до ряду проблем з компенсацією надлишкової реактивної потужності. Варіантом розв'язання таких проблем може бути застосування асинхронізованих генераторів, що мають ряд переваг перед традиційними синхронними генераторами. Ці переваги у значній мірі проявляють себе в умовах роботи генератора у мережах із надлишковою реактивною потужністю. Типовим прикладом такої мережі є мережа надвисокої напруги "Острова БуТЕС" та "Енергомоста "Україна-СС". В роботі наведено результати математичного моделювання режимів мережі "Енергомоста "Україна-СС". Координати режимів визначалися для різних варіантів схеми та режимів роботи генератора. Отримані результати доводять можливість та ефективність пропонованого технічного рішення.

Ключові слова: асинхронізований генератор; асинхронізований режим; асинхронний режим; надвисоковольтна мережа; "Енергоміст "Україна-СС". 